\title{
KAITAN PEMBELAJARAN BAHASA INDONESIA DENGAN LINGKUNGAN
}

\author{
Rizki Fitiani/19016046 \\ rfitriani283@gmail.com
}

Penguasaan sebuah bahasa oleh seorang anak dimulai dengan perolehan bahasa pertama yang sering kali disebut bahasa ibu. Menurut Kridalaksan (dalam Suardi ed el, 2019), bahasa merupakan sistem lambang bunyi yang arbitrer yang digunakan oleh anggota kelompok sosial untuk bekerja sama, berkomunikasi, dan mengidentifikasikan diri. Lingkungan merupakan tempat terjadinya sebuah interaksi, dimana interaksi yang terjadi antara manusia dilakukan melalui berkomunikasi. Menurut Nadar (dalam Stambo et el, 2019), prakmatik merupakan cabang linguistik yang mempelajari bahasa yang digunakan untuk berkomunikasi dalam situasi tertentu. Sebagai warga Negara Indonesia kita harus paham mengenai cara berkomunikasi dan pemakaian bahasa yang baik karena kita adalah bangsa dengan masyarakat yang beragam. Sukma (2020), berpendapat penanaman karakter penting diusahkan sejak siswa masih duduk dibangku sekolah dasar. Penanaman karakter dapat dilakukan dalam proses pembelajaran bahasa di sekolah. Penanaman karakter dari kecil dapat mempermudah segala aspek dalam kehidupan baik berprilaku maupun berbahasa yang santun.

Menurut Sumarsono (dalam Halawa ed el, 2019), kesantunan bertutur merupakan salah satu aspek kebahasaan yang dapat meningkatkan kecerdasan emosional penuturnya karena didalam komunikasi, penutur dan petutur tidak hanya dituntut menyampaikan kebenaran, tetapi harus tetap berkomitmen untuk menjaga keharmonisan hubungan. Keharmonisan hubungan haruslah sangat dijaga dengan meperhatikan cara kita berkomunikasi. Menurut Yule (dalam Larassaty et el, 2016), strategi bertutur adalah bagaimana cara kita bertutur agar menghasilkan suatu ujaran yang menarik dan dapat dimengerti oleh lawan tutur. Strategi bertutur biasa digunkan dalam suatu kelompok tutur atau tersebar secara keseluruhan atau hanya dipakai oleh seorang penutur pada waktu tertentu. Berdasarkan urutan tingkat ketidak langsungan yang semakin naik, strategi bertutur menurut Brown dan Levinson (dalam Larassaty et el, 2016), sebagai berikut ini. Pertama, strategi bertutur terus terang tanpa basa-basi. Kedua, strategi bertutur dengan basa-basi kesantunan positif. Ketiga, strategi bertutur dengan basa-basi 
kesantunan negatif. Keempat, strategi bertutur samar-samar. Kelima, strategi bertutur dalam hati atau diam.

Menurut Lai dan Buldur (dalam Ramadhan et al, 2019), pendidikan lingkungan dapat diaplikasikan dalam proses pembelajaran langsung di kelas. Pembelajaran bahasa Indonesia sangat erat kaitannya dengan lingkungan, oleh karenanya diharapkan kontribusi aktif dari segala kalangan masyarakat ikut dalam memotivasi peserta didik untuk belajar. Nkwetisma (dalam Ramadhan et al, 2019), menyatakan pendidikan lingkungan merupakan suatu usaha yang dilakukan secara sadar untuk mengajar dan menarik perhatian manusia tentang bagaimana fungsi lingkungan alam dan bagaimana manusia ini dapat mengelola dan melindunginya. Menurut Onu (dalam Zulhalfizh et el, 2013), motivasi belajar yang tinggi dapat membuat siswa tekun dalam belajar dan tidak mudah terpengaruh dengan hal lain, sebaliknya siswa yang kurang atau tidak memiliki motivasi belajar memungkinkan dia tidak tahan lama dalam belajar.

Sukma (2017), berpendapat kemampuan dalam berliterasi memiliki pengaruh yang signifikan terhadap keberhasilan siswa dalam belajar dan kehidupan sehari-hari. Saat siswa mampu berliterasi dengan baik, maka siswa tersebut akan mudah memahami teks (lisan) dan memproduksi teks (tulisan). Sukma (2019), menyatakan guru hendaknya memberikan motivasi kepada siswa. Guru harus mampu menciptakan pengalaman dalam pembelajaran, hingga dapat membuat siswa termotivasi untuk belajar. Dalam pelaksanaanya kita juga harus mengetahui bagaimana pelaksanaan literasi yang telah dilaksanakan di sekolah. Walaupun lingkungan dan masyarakat sangat menentukan motivasi belajar bahasa Indonesia, tapi guru tetaplah merupakan fasilitator utama bagi siswanya. Hal ini sejalan dengan pernyataan Sukma (2012), yaitu guru adalah fasilitator dan manajer pembelajaran dalam proses pembelajaran.

Berdasarkan angket yang penulis sebarkan mengenai "Kaitan Pembelajaran Bahasa Indonesia dengan Lingkungan" kepada mahasiswa Universitas Negeri Padang semester 5, Universitas Negeri Padang semester 3, mahasiswa Inaitusi Kesehatan Prima Nusantara Bukittinggi semester 5, mahasiswa Universitas Islam Sumatra Utara (UINSU) semester 3, mahasiswa Universitas Putra Indonesia (YPTK) semester 3, mahasiswa Universitas Bung Hatta semester 5, mahasiswa Universitas Muhammadiyah Prof. Dr. Hamka (UHAMKA) semester $7 .$. Dari jumlah keseluruhan 32 responden yang ikut serta mengisi angket tersebut yang 
respondennya $100 \%$ perempuan. Hasil data dari persentase angket yang telah dilakukan melalui google form tersebut dapat dilihat sebagai berikut.

Pernyataan pertama, "Mata pelajaran Bahasa Indonesia adalah mata pelajran yang wajib kita kusai, 28,1\% menyatakan sangat setuju, 62,5\% menyatakan setuju, 9,4\% menyatakan kurang setuju, dan 0\% menyatakan tidak setuju. Pernyataan kedua, "Setiap aspek dalam lingungan masyarakat dapat menjadi sumber dari pembelajaran bahasa Indonesia" 25\% menyatakan sangat setuju, 75\% menyatakan setuju, $0 \%$ menyatakan kurang setuju, dan $0 \%$ menyatakan tidak setuju. Pernyataan ketiga, "Masyarakat pada umumnya masih ragu dalam penggunaan bahasa Indonesia baik secra lisan ataupun tulisan” 25\% menyatakan sangat setuju, 68,8\% menyatakan setuju, 6,3\% menyatakan kurang setuju, dan $0 \%$ menyatakan tidak setuju. Pernyataan keempat, "Dalam penerapannya, bahasa Indonesia yang baik dan benar masih dianggap awam, karena masyarakat lebih terbiasa menggunakan bahasa asing ataupun bahasa kekinian" 12,5\% menyatakan sangat setuju, 87,5\% menyatakan setuju, 0\% menyatakan kurang setuju, dan 0\% menyatakan tidak setuju. Pernyataan kelima, "Lingkungan dan masyarakat sekitar dapat mempengaruhi perkembangan bahasa pada anak." 53,1\% menyatakan sangat setuju, 47,9\% menyatakan setuju, $0 \%$ menyatakan kurang setuju, dan $0 \%$ menyatakan tidak setuju. Pernyataan keenam, "Siswa yang sedang mempelajari mengenai teks deskripsi dapat menjadikan lingkungan dan masyarakat sekitarnya sebagai objek dari penulisan teks deskripsi tersebut." 29,1\% menyatakan sangat setuju, 78,1\% menyatakan setuju, 0\% menyatakan kurang setuju, dan 0\% menyatakan tidak setuju. Pernyataan ketujuh, "Bahasa Indonesia adalah salah satu bahasa yang mudah dipelajari” 25\% menyatakan sangat setuju, 65,6\% menyatakan setuju, 9,4\% menyatakan kurang setuju, dan 0\% menyatakan tidak setuju. Pernyataan kedelapan, "Pembelajaran berbasis lingkungan, mengajarkan siswa untuk berkontribusi aktif terhadap kelestarian lingkungan" 25\% menyatakan sangat setuju, 71,9\% menyatakan setuju, 3,1\% menyatakan kurang setuju, dan 0\% menyatakan tidak setuju. Pernyataan kesembilan, "Dalam pembelajaran teks prosedur, kita dapat mengajarkan kepada anak prosedur atau langkahlangkah yang dapat dilakukan untuk melestarikan lingkungan." 25\% menyatakan sangat setuju, $75 \%$ menyatakan setuju, $0 \%$ menyatakan kurang setuju, dan $0 \%$ menyatakan tidak setuju. Pernyataan kesepuluh, "Bahasa Indonesia dapat menjadi bahas Internasional jika memiliki penutur yang banyak dan penyebaran yang luas. Dari pernyataan itu dapat disimpulkan bahwa, kita sebagai masyarakat Indonesia harus melestarikan dan bangga menggunakan bahasa 
Indonesia" 59,4\% menyatakan setuju, 40,6\% menyatakan sangat setuju, $0 \%$ menyatakan kurang setuju, dan $0 \%$ menyatakan tidak setuju.

Jadi, dapat disimpulkan bahawa hasil dari penyebaran angket yang telah dilakukan menunjukkan keterkaitan anatara lingkungan dan masayarakat dalam pembelajaran bahasa Indonesia. Hal ini terlihat dari jawaban para reponden yang menggap peranan dan manfaat lingkungan dan masyarakat dalam pembelajaran bahasa Indonesia merupakan suatu hal penting. Masyarakat, khususnya di kalangan mahasiswa dan pelajar, menyadari dan memahami pentingnya peranan lingkungan dalam pembelajaran bahasa Indonesia. Menurut penulis, kesadaran masyarakat terhadap peran dan manfaat lingkungan dalam pembelajaran bahasa Indonesia sudah dapat dikategorikan baik. Sebagai fasilitator utama guru dalam proses pembelajaran sudah dipermudah, karena kesadaran masyarakat lingkungan. Siswa pun dapat mengembangkan kemampuan berbahasa dengan baik, karena lingkungannya sudah banyak yang member memotivasi dan pengetahuan betapa pentingnya berbahasa dan mempelajari bahasa Indonesia. 


\section{Daftar Pustaka}

Halawa, Noibu., Erizal Gani., Syahrul Ramadhan. (2019). Kesantunan Berbahasa Indonesia dalam Tindak Tutur Melarang dan Mengkritik pada Tujuh Etnis.Lingua XV (2), 195-205.

Larassaty, Suci., Syahrul Ramadhan., Erizal Gani. (2016). Representasi Tindak Tutur Direktif Bahas Indonesia Siswa Kelas XI SMA Negri 15 Padang. Jurnal Pendidikan Bahasa dan Sastra Indonesia 5 (2) .

Ramadhan, S., Sukma, E., \& Indriyani, V. (2019). Environmental education and disaster mitigation through language learning. IOP Conference Series: Earth and Environmental Science, 314.

Suardi, Indah Permata Sari., Sayhrul. R., Yasnur Asri. (2019). Pemerolehan Bahasa Pertam pada Anak Usia Dini. Jurnal Obsesi : Jurnal Pendidikan Anak Usia Dini 3 (1), 265-273.

Sukma, Elfia. (2012). Pembelajaran Sastra yang Integratif Berbasis Kompetensi. International Conference on Languages and Arts, Halaman 432-436.

Sukma E, Ritawati M, dan Rizky A. (2017). Literacy Media Development in Improving Reading and Writing Skill of Early Class Students in Elementary School Padang Utara Padang. Advances in Social Science, Education and Humanities Research, Vol 118.

Sukma E. et.al. (2019). Problems in Oral Language Teaching in Primary School. Advances in Social Science. Education and Humanities Research, Volume 301.

Sukma E, dan VP Azrianti. (2020). Instilling Positive Characters in Students Using Folker in the Macromedia Application. Advances in Social Science, Education and Humanities Research, Volume 485.

Stambo,Rolo., Syahrul Ramadhan. (2019). Tindak Tutur Ilokusi Pendakwah dalam Program Damai Indonesiaku di Tv One. BASINDO : Jurnal Kajian Bahasa, Sastra Indonesia, dan Pembelajarannya 3(2). 
Zulhafizh., Atmazaki., Syahrul Ramadhan. (2013). Kontribusi Sikap dan Motivasi Belajar Siswa terhadap Hasil Belajar Bahasa Indonesia. Jurnal Bahasa, Sastra dan Pembelajaran 1 (2), 13-26. 